\title{
Factors and Benefits that Affect Lender's Interest in Giving Loans in Peer to Peer (P2P) Lending Platform
}

\author{
Christiana Fara Dharmastuti ${ }^{1 *}$; Jonathan Laurentxius ${ }^{2}$ \\ 1,2Management Department, Faculty of Economics and Business, \\ Atma Jaya Catholic University of Indonesia \\ Jln. Jend. Sudirman No.51, Jakarta Selatan 12930, Indonesia \\ 'christiana.fara@atmajaya.ac.id; 2jonathanlaurentxius@gmail.com
}

Received: $1^{\text {st }}$ April 2020/ Revised: $9^{\text {th }}$ July 2020/ Accepted: $22^{\text {nd }}$ October 2020

How to Cite: Dharmastuti, C. F., \& Laurentxius, J. (2021). Factors and Benefits that Affect Lender's Interest in Giving Loans in Peer to Peer (P2P) Lending Platform. Binus Business Review, 12(2), 121-130.

https://doi.org/10.21512/bbr.v12i2.6359

\begin{abstract}
Financial technology (fintech) is a combination of the financial industry and technology. One of the uses of fintech is the Peer to Peer (P2P) lending platform, which is a funding channel. This platform is an investment alternative that can increase borrowers' and investors' prosperity. However, P2P also has a high risk that must be considered. Lenders or investors must conduct a loan application feasibility study before giving a loan. The research examined the impact of Character, Capital, Capacity, Collateral (4C) and the benefits that lenders received, as well as the benefits of fintech on lenders' interest in placing their funds on the P2P lending platform. Data were obtained from questionnaires distributed to $\mathrm{P} 2 \mathrm{P}$ lending users. The sampling technique was purposive sampling. The total number of respondents who returned the questionnaire was 70 respondents. However, only 53 data could be used in the research. Then, the data were analyzed using Moderated Regression Analysis (MRA). The results show that the 4C factors do not significantly affect the lenders' interest in giving loans. Meanwhile, the benefits and fintech have a significant direct impact. Fintech cannot act as a moderator variable in this model. P2P companies must provide complete information and credit analysis regarding borrowers' conditions to reduce lenders' potential risk.
\end{abstract}

Keywords: 4C factors, lender, interest, loans, P2P lending platform

\section{INTRODUCTION}

The development of information technology, especially the Internet, has contributed to the change in the global business model. Many things that are previously done conventionally can now be done more efficiently and practically with technology. Until now, the Internet has become an ideal infrastructure for conducting business practices with a broader range of consumers. The changes in technology also affect business models in the financial sector. A combination of the financial industry with this technology is called financial technology or better known by its abbreviation, fintech. Fintech provides a disruptive potential for the financial sector. It goes beyond a simple linear continuation of existing developments (Alt, Beck, \& Smits, 2018).
According to Iman (2018), the keywords in fintech are technology, service providers, banking, financial services, and disruptive. Implicitly, it illustrates that the flexibility causes fintech to offer several services from payment, investment, funding, insurance, and supporting infrastructure. Then, several theories can explain the importance of fintech in the business world, such as agency costs, transaction costs, network externalities, multi-sided platforms, and disruptive innovations. Through agency costs, which are the form of internal costs that must be paid to parties acting as agents, there is a separation between principals and management as agents. Transaction costs are costs that increase when entities make economic exchanges or participate in the market. These costs increase in information-seeking costs, bargaining costs, monitoring costs, and law 
enforcement costs. Technology innovation, in general, can reduce agency costs by making agents more accountable and transparent to principals and making the cost of finding information cheaper.

Next, network externalities are the effects of users of the same product or service from others. For example, for millennials, it will look "cool" if they use fintech. Meanwhile, multi-sided platforms are an explanation of the importance and breadth of technology because they can bring this business model together from two or more independent user groups. This interaction is a facility of a platform that can cause mutual connectivity between users and consumers. For example, Peer to Peer (P2P) lending connects the owner of the funds and those who need funds. The platform owner will set a percentage for managing this interaction. Meanwhile, disruptive innovations are the process in which products and services are offered in simple applications in the lower market, causing market penetration to occur at a level. This process can replace existing incumbents.

Fintech firms also create innovation. One of the most popular measures of innovation output is patents. From 1998-2016, the total patent has increased from 3.799 patents/year to 10.662 patents/year with an average of 91,91 patents/company (Unsal \& Rayfield, 2019). The data show that innovation in the field of fintech is increasing rapidly. Many variables that affect innovation found in the literature are correlated with financial innovation. For example, total assets, number of employees, and market capitalization are all significantly positively related.

According to Financial Services Authority (Otoritas Jasa Keuangan), fintech is a combination of digital and finance (Gunadi, 2018). Digital is related to data and information as well as values (money), and financial matters are related to finance. There are three things in its implementation: payment, financing (peer to peer or crowdfunding), and management (supporting, management, and insurance). Fintech can provide three main benefits in cost, time, and space. It is further conveyed that Financial Services Authority distinguishes the basic things between financial institutions that currently exist with digital financial innovation. The differences can be seen in Table 1 .

Fintech provides opportunities to create new services and business models and poses challenges to traditional financial service providers. Fintech provides new opportunities to empower people by increasing transparency, reducing costs, eliminating the role of intermediaries, and making financial information easily accessible (Zavolokina, Dolata, \& Schwabe, 2016). According to Fintechnews Singapore (2018), the distribution of fintech use in Indonesia is dominated by payment (38\%) and lending (31\%). This report also shows that only $48,9 \%$ of the total Indonesian people have conventional bank accounts, and $17,2 \%$ borrow from financial institutions. Based on the data and looking at the percentage of lending $(31 \%)$ as the second-largest distribution of fintech in Indonesia, the development of fintech in the lending field is an exciting thing that can still touch more than $80 \%$ of Indonesian people.

Lending or P2P lending in fintech offers a new investment channel. P2P lending provides an alternative but important funding or investment channel that can improve the welfare of borrowers and lenders (Jiang, Liao, Wang, \& Zhang, 2021). P2P lending is online micro-financing that lenders and borrowers meet virtually for loan transactions. Along with the high growth, there is a high risk in $\mathrm{P} 2 \mathrm{P}$ lending due to uncollateralized loans, information asymmetry, and lack of expertise on borrowers' creditworthiness. Therefore, it is highly necessary to analyze the credit risk of borrowers in peer-to-peer lending (Byanjankar, 2017).

Table 1 Differences of Financial Service Institutions and Digital Financial Innovations

\begin{tabular}{|c|c|c|}
\hline & $\begin{array}{l}\text { Incumbents or Financial Service } \\
\text { Institution }\end{array}$ & Digital Financial Innovation \\
\hline Business model & Centralized business model & Distributed business model \\
\hline Risk model & Risk exposure and risk transformation & $\begin{array}{l}\text { No risk exposure and transformation (manage } \\
\text { operational risks of business activities only) }\end{array}$ \\
\hline Legal arrangement & Customers with financial service institution & Customer with customer \\
\hline Intermediation & Financial intermediation & Financial disintermediation \\
\hline Income & Interest and fee-based income & Fee-based income \\
\hline Disclosure & $\begin{array}{l}\text { Limited transparency (confidentiality } \\
\text { guaranteed) }\end{array}$ & Transparency-based \\
\hline $\begin{array}{l}\text { Supervisory } \\
\text { approach }\end{array}$ & Prudential & Market conduct \\
\hline
\end{tabular}

(Source: Gunadi, 2018) 
Informal loans are often characterized by lowvalue but high-frequency transactions. This type of lending is a characteristic of P2P lending. Moreover, it is commonly found in developing countries. Fintech, through the P2P lending platform, happens in many communities and other types of lending. It actively changes informal lending. Through this platform, fintech provides a more organized mechanism for borrowing and building transparency within the scope of informal loans.

$\mathrm{P} 2 \mathrm{P}$ lending is a form of loan where transactions are carried out between individuals directly. The number of funds and payment type are mutually dependent on the agreement between the borrowers and the lenders. Lenders' profits are often larger than formal lending systems. The obtained interest rate from lending is usually decided by several considerations and the environment that underlies the borrowers and lenders. P2P lending provides an alternative but important funding or investment channel, which has the potential to improve the welfare of borrowers and lenders (Jiang et al., 2021). This platform does not bear credit risk from loans. Credit risk is borne by investors (lenders) (Stern, Makinen, \& Qian, 2017).

Asymmetric (unbalanced) information is a fundamental problem in online P2P lending. The influence of loan descriptions from borrowers on the success of funding needs to be investigated (Bachmann et al., 2011). Factors affecting lenders' interest or the criteria that lenders use to select borrowers are essential because most P2P lending sites have minimal traditional financial information about borrowers, especially when the borrower does not have an account with a bank, or this is the first time. Hence, $\mathrm{P} 2 \mathrm{P}$ lending is often considered unsafe due to the lack of traditional financial data (Sukmaningsih, 2018).

In P2P lending, the effect of the economic benefit is an important factor in using it continuously (Ryu, 2018). The crowdfunding user groups illustrate that the economic benefit is the highest perceived factor. Economic benefits are extrinsic motivation in using fintech. The intended economic benefits include financial gain and cost reduction from fintech transactions. More specifically, the use of fintech in P2P lending and crowdfunding offers higher returns to lenders and lower interest rates to borrowers through platforms with lower overhead costs.

According to Lin, Cai, Xu, and Fu (2015), the beginning of the interest rate and the duration of the return (payback period) affect the success of loan funding. When lenders consider whether to choose an offer, they will pay a lot of attention to weighing several questions. For example, how much the borrower wants, how long they will get repayment, and how the results they receive.

In its development, P2P lending increased very rapidly with various offered platforms. The borrowers and lenders have various facilities on an informal basis and have many benefits. However, it has a high potential risk because it depends on the borrowers. In the P2P lending business model, the credit risk is assumed by individuals who put risk in their money lending to other individuals. The information asymmetry problem is huge (Serrano-Cinca, Gutiérrez-Nieto, \& López-Palacios, 2015). Therefore, the borrowers need to show more credit guarantees for their offer and need to make the lenders believe that the offer is safe enough (Lin et al., 2015)

In short, fintech companies are challenged to increase the potential benefits of using fintech and limit potential risks at the same time (Ryu, 2018). The risk of investment failure is strongly associated with the uncollateralized nature of loans and information asymmetry. The high cost is associated with credit risk management measures. It is applied by conventional banking to strengthen the trust in borrowers. Hence, it is difficult to be applied in P2P lending (Byanjankar, 2017). As lenders or investors, it is necessary to conduct a feasibility study of a loan application before giving a loan. Through the management of accounts receivable policies, an analysis can be used to reduce the potential risks occurring in the credit plan. This analysis helps the customers to fulfill their duties to the creditors in accordance with the agreement. Moreover, the development and high potential of P2P lending provide benefits for the community's prosperity, but it has a high potential risk. Lenders run the risk of losing funds or defaults from the borrowers. Based on the data from the Financial Services Authority, the Non-Performing Loans (NPL) in P2P lending have continued to increase from 2019 to 2020 (Hutapea, 2020).

In general, from financial management, the used tool to look at the feasibility of borrowers to be given funds and predict the possibility of bad credit is five " $\mathrm{C}$ " consisting of Character, Capital, Capacity, Collateral, and Condition of Economic (Baiden, 2011; Ross, Westerfield, \& Jordan, 2016; Riyanto, 2013). Through creditworthiness analysis, the lender will gain confidence whether the customer has the will and ability to fulfill the obligations in an orderly manner in the loan principal and interest payments, according to the agreement with the creditor.

Character is the creditor's information about prospective borrowers to determine the extent of honesty, integrity, and reasonable determination. For example, it can be the willingness to fulfill the obligations as a borrower. If the creditor assesses the borrower having positive credibility, the level of the risk of uncollectible debt gets smaller so that the creditor decides the higher lending.

Capacity is the ability of the borrowers to manage their businesses that will be financed with credit. If their capacity is high, the risk of uncollectible debt will be smaller. Then, creditors will make substantial credit decisions.

Next, capital describes the number of funds owned by a prospective borrower. It can be seen from the given financial statements. If the owned capital is large, the possibility of uncollectible debt risk will be less. Then, collateral is a security tool if the business finance fails or, for some reason, the borrower can no 


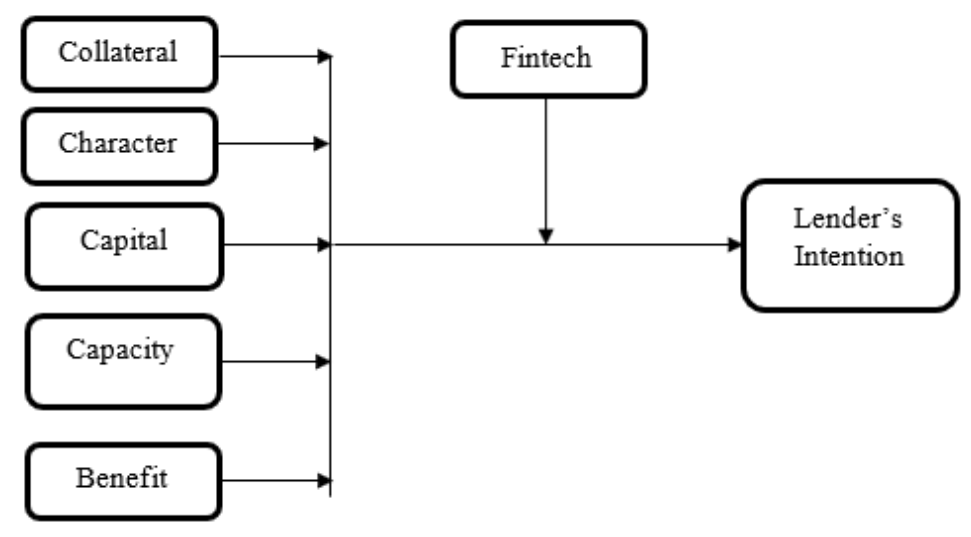

Figure 1 Research Model

longer pay off the credit.

Condition of economic describes the economic, political, and other situations and conditions that affect the state of the economy. It is likely to affect the smooth operation of the borrowers' business activities. It refers to the sensitivity of the borrower to external factors such as interest rates, inflation, business turnover, and competition in business (Moti, Masinde, Mugenda, \& Sindani, 2012). However, this factor is not used in the research because the researchers want to see the potential risk that comes from internal factors in borrowers.

Based on this phenomenon, the research aims to analyze whether lenders pay attention to the borrower's risk factors or pay more attention to profits in influencing their decision to place their money on the P2P lending platform. It also emphasizes fintech factors in influencing investors' decisions. Borrower's risk factors will be analyzed through Character, Capital, Capacity, and Collateral (4C). From the perspective of financial management, lenders need to analyze borrowers' benefits and potential risks through 4C. By analyzing the two things, it can influence the intention of lenders to place their funds on P2P lending by seeing the use of fintech in the transaction platform. Based on this premise, the research model is constructed in Figure 1.

\section{METHODS}

The research uses primary data obtained from the results of questionnaires. The questionnaires are distributed to respondents who have ever given loans through P2P lending. The sampling technique is purposive sampling. The total number of respondents who returns the questionnaire is 70 respondents. However, only 53 data can be used because those understand and have provided P2P lending loans. For the assessment of questionnaires, it uses a Likert scale of $1-5$.
There are several operational variables in the research. First, collateral indicates its presence or absence to the borrower in an offer of money lending. Second, the character is measured through a history of refunds from the borrower, whether the payments by the borrower are on time or late, or even unpaid. Third, capital is seen from financial information. The company's financial information shows the performance or financial condition of the borrower's business. The intended financial information is income, debt to equity ratio, and debt to asset ratio. Fourth, capacity is from the grade (credit level) in assessing the borrower's credit risk, the ability to pay back, and the possibility of default. Credit grade is divided into several classes from $\mathrm{A}$ to $\mathrm{F}$, with $\mathrm{A}$ as the best predicate. Meanwhile, the minimum credit grade to raise funds is $\mathrm{C}$.

Fifth, benefits are measured from two factors. Interest rate is a variable that shows the percentage of lead that lenders will obtain in an offer of lending money in a period. It generally displays the percentage of interest in a year. Then, duration is the period of repayment of the principal loan value. The displayed duration is in the unit of months.

Sixth, fintech is measured by the ease and use of technology in financial transactions. Seventh, the lender's intention is the interest to provide loans. It is the willingness of lenders to offer loans to borrowers.

The data are analyzed using Moderated Regression Analysis (MRA). Besides the independent variable, the research includes a moderating variable that is the fintech. Before conducting data analysis, tests of validity, reliability, and classical assumption are done using the SPSS program.

\section{RESULTS AND DISCUSSIONS}

The descriptive data in Table 2 show that most respondents are male $(73,58 \%)$. They are born around $>1991-1998$ (50,94\%). Most of them have 
undergraduate education $(62,26 \%)$ followed by graduate education $(22,64 \%)$. So, it can be seen that the younger generation (millennial) and educated scholars understand more about fintech applications, especially P2P lending.

Table 2 Demographics of Respondents

\begin{tabular}{lcc}
\hline Gender & Amount & Percentage \\
\hline Male & 39 & $73,58 \%$ \\
Female & 14 & $26,42 \%$ \\
\hline Total Respondent & 53 & $100,00 \%$ \\
\hline Birth Year & Amount & Percentage \\
\hline$>1991-1998$ & 27 & $50,94 \%$ \\
$>1968-1984$ & 13 & $24,53 \%$ \\
$>1984-1991$ & 8 & $15,09 \%$ \\
$\leq 1968$ & 5 & $9,44 \%$ \\
\hline Total Respondent & 53 & $100,00 \%$ \\
\hline Education & Amount & Percentage \\
\hline Undergraduate & 33 & $62,26 \%$ \\
Graduate & 12 & $22,64 \%$ \\
Post Graduate & 4 & $7,55 \%$ \\
Diploma & 3 & $5,66 \%$ \\
$\leq$ High School, & 1 & $1,89 \%$ \\
Vocational School, or & & \\
Equivalent & & \\
\hline Total Respondent & 53 & $100,00 \%$ \\
\hline
\end{tabular}

The hypothesis in the research is that the benefits and potential risks of borrowers can influence lenders' intention to place their funds in P2P lending, with fintech as a moderating variable. Before testing the hypothesis, validity and reliability tests are performed to ensure that the used questionnaires are good and can be trusted. The research compares the value of $r$-count with $\mathrm{r}$-table with a degree of freedom $(\mathrm{df})=\mathrm{n}-2(\mathrm{df}$ $=53-2$ ) to test the validity of 53 respondents. Then, the r-table of 0,273 is compared with each value of corrected item-total correlation. The whole questions have a greater value than the r-table. Meanwhile, for the reliability test, it can be seen from Cronbach's alpha value. Based on the statistical test, all questions are reliable because it has a Cronbach's alpha value of $>0,6$.

Moreover, it is necessary to test the classical assumptions. The multicollinearity test shows that all variables (benefit, capacity, collateral, capital, character) have a VIF value of $<10$. Hence, there is no multicollinearity. Then, the autocorrelation test uses the Durbin Watson test with five independent variables with 53 respondents. The obtained value is 2,314 . Meanwhile, the table value is with a significance level of $0,05: \mathrm{dl}=1,7689$ and $\mathrm{du}=1,3592$. Thus, $\mathrm{dl}$ is bigger than $\mathrm{du}$. There is no autocorrelation.
The heteroscedasticity test uses plots of scattered image points. It does not form certain patterns. It can be stated that there is no heteroscedasticity in the research model. Meanwhile, the normality test shows a picture that the points are distributed around a diagonal line. It indicates that it meets the normality assumption. The results can be seen in Figures 2 and 3.

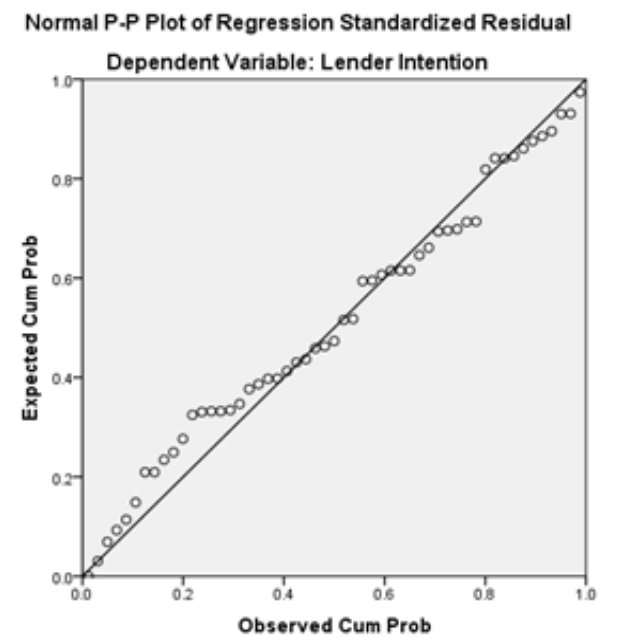

Figure 2 Heteroscedasticity Test

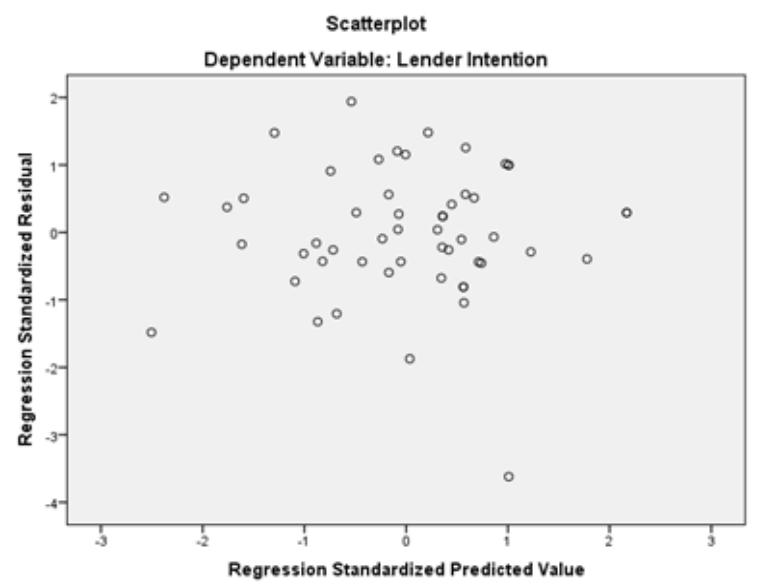

Figure 3 Normality Test

Next, MRA is used to test the proposed hypothesis. The first hypothesis is that lender's intention is only influenced by $4 \mathrm{C}$ and benefit. The results are in Table 3.

Table 3 shows that the probability of ANOVA with an alpha level of 0,05 results in 0,005. These results indicate that this model can be used to explain the lender's intention. It is influenced by $4 \mathrm{C}$ and benefit simultaneously. The R-squared value indicates that the dependent variable can explain the independent variable by $29,1 \%$. Meanwhile, the rest is influenced by other factors. From the independent variables, it turns out that benefit has a significant positive effect on lender's intention $(\beta=0,488, t=3,715$, and $\mathrm{P}=$ $0,001<0,05)$. Hence, the hypothesis is supported. 
Table 3 The Results of the First Hypothesis

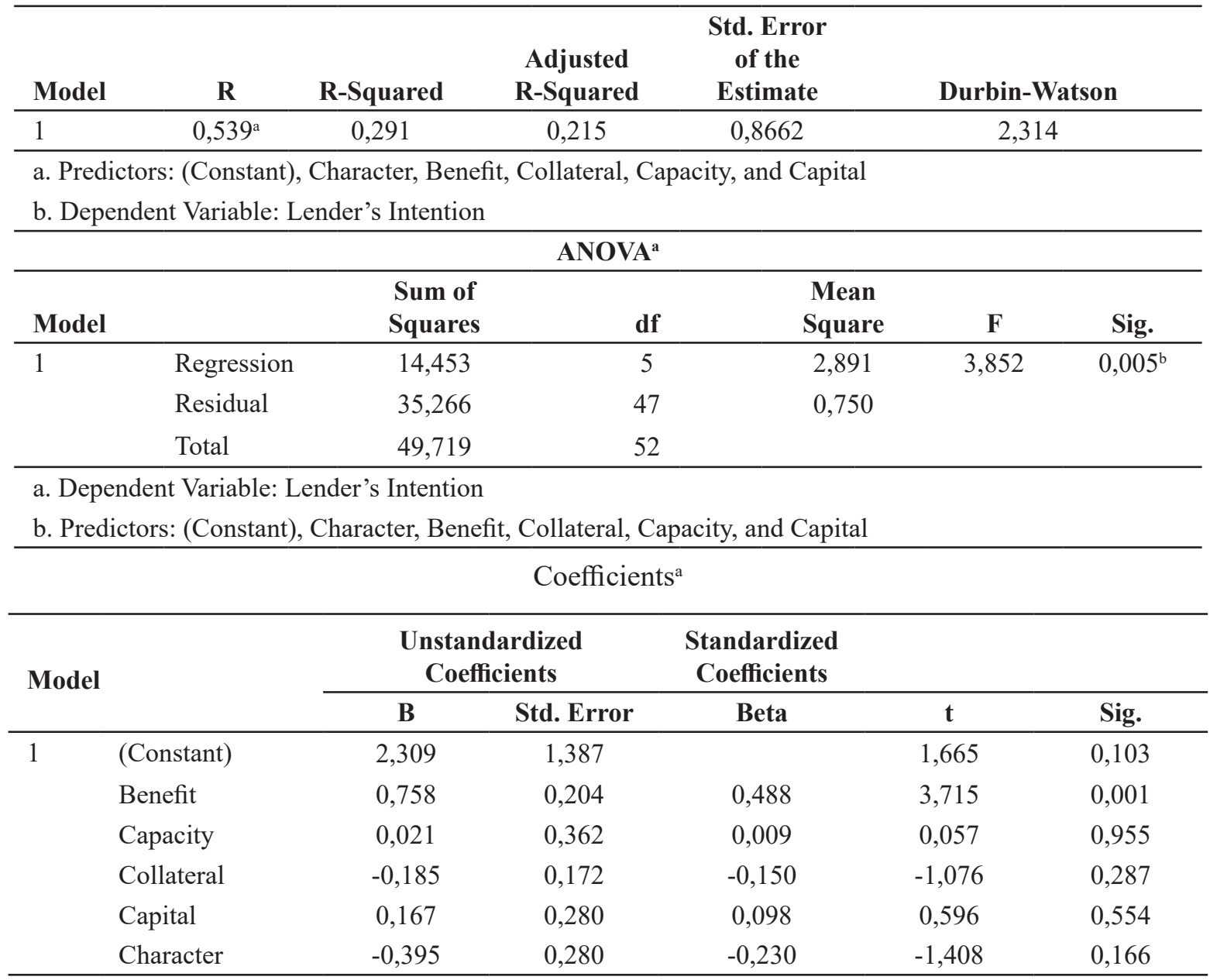

Meanwhile, the potential risk of borrowers as measured using $4 \mathrm{C}$ are not significant with capacity of $\mathrm{P}=0,995$ $>0,05$, collateral of $\mathrm{P}=0,287>0,05$, capital of $\mathrm{P}=$ $0,554>0,05$, and character of $0,166>0,05$. Thus, the hypothesis is not supported.

The second hypothesis shows that the lender's intention is influenced by $4 \mathrm{C}$, benefit, and fintech application. The results have a higher R-squared value of 0,660 . It means that the independent variables have a larger influencer on the dependent variable. Then, the significance level is 0,000 . The results can be seen in Table 4.

The research includes fintech as the dependent variable. When the test is performed for each variable, it shows that the benefit with a significance of 0,002 and the fintech with a significance of 0,000 affect the lender's intention significantly. Meanwhile, $4 \mathrm{C}$ does not have a significant effect.

In the third hypothesis, the fintech becomes a moderating variable to strengthen the influence of the $4 \mathrm{C}$ and benefit on the lender's intention. The model has a significant effect with a significance ( $F$ of 7,682, Sig. of $0,000<0,05$, and an R-squared value of 0,679$)$. However, when tested on each variable, fintech as a moderating variable does not have a significant effect. Thus, the hypothesis is not supported. The result are shown in Table 5.

There are several results of testing the proposed hypothesis. It turns out that $4 \mathrm{C}$ as a potential risk factor of the borrower does not affect the lender's intention to provide loans through the P2P lending platform. However, the benefit has a significant positive effect on the lender's intention.

Platforms in P2P lending often have minimal data. Unbalanced information is an important factor in P2P lending (Cummins, Lynn, Mac an Bhaird, \& Rosati, 2019). Lenders will only analyze and obtain information from what is displayed on the platform. Then, the unavailability of information on financial data based on traditional calculations makes the credit rating system at fintech different. It has the potential to increase credit risk (Leong, Tan, Xiao, Tan, \& Sun, 2017). This condition causes lenders not to trust the information in the $\mathrm{P} 2 \mathrm{P}$ lending platform.

Moreover, P2P lending is a form of loan that the transactions are carried out between individuals directly. The number of funds and the kind of payment are mutually dependent on the borrower's and lender's agreement. Thus, the credit risk analysis will depend on how the lender has the ability to find the information about the borrower. 
Table 4 The Results of the Second Hypothesis

\begin{tabular}{|c|c|c|c|c|c|c|}
\hline Model & $\mathbf{R}$ & R-Squared & $\begin{array}{c}\text { Adjusted } \\
\text { R-Squared }\end{array}$ & $\begin{array}{l}\text { Std. Error } \\
\text { of the } \\
\text { Estimate }\end{array}$ & \multicolumn{2}{|c|}{ Durbin-Watson } \\
\hline 1 & $0,812^{\mathrm{a}}$ & 0,660 & 0,616 & 0,6063 & \multicolumn{2}{|c|}{2,105} \\
\hline \multicolumn{7}{|c|}{ a. Predictors: (Constant), Fintech, Collateral, Benefit, Capital, Capacity, and Character } \\
\hline \multicolumn{7}{|c|}{ b. Dependent Variable: Lender's Intention } \\
\hline \multicolumn{7}{|c|}{ ANOVA $^{\mathrm{a}}$} \\
\hline Model & & $\begin{array}{l}\text { Sum of } \\
\text { Squares }\end{array}$ & df & $\begin{array}{c}\text { Mean } \\
\text { Square }\end{array}$ & $\mathbf{F}$ & Sig. \\
\hline \multirow[t]{3}{*}{1} & Regression & 32,811 & 6 & 5,468 & 14,877 & $0,000^{\mathrm{b}}$ \\
\hline & Residual & 16,908 & 46 & 0,368 & & \\
\hline & Total & 49,719 & 52 & & & \\
\hline \multicolumn{7}{|c|}{ a. Dependent Variable: Lender's Intention } \\
\hline \multicolumn{7}{|c|}{ b. Predictors: (Constant), Fintech, Collateral, Benefit, Capital, Capacity, and Character } \\
\hline \multicolumn{7}{|c|}{ Coefficients $^{\mathrm{a}}$} \\
\hline \multirow[t]{2}{*}{ Model } & & \multicolumn{2}{|c|}{ Unstandardized Coefficients } & $\begin{array}{r}\text { Standardi } \\
\text { Coefficier }\end{array}$ & & \\
\hline & & B & Std. Error & Beta & $\mathbf{t}$ & Sig. \\
\hline \multirow[t]{7}{*}{1} & (Constant) & 0,782 & 0,994 & & 0,786 & 0,436 \\
\hline & Benefit & 0,494 & 0,148 & 0,318 & 3,350 & 0,002 \\
\hline & Capacity & $-0,107$ & 0,254 & $-0,047$ & $-0,420$ & 0,676 \\
\hline & Collateral & $-0,124$ & 0,121 & $-0,100$ & $-1,024$ & 0,311 \\
\hline & Capital & $-0,034$ & 0,198 & $-0,020$ & $-0,172$ & 0,864 \\
\hline & Character & $-0,314$ & 0,197 & $-0,183$ & $-1,598$ & 0,117 \\
\hline & Fintech & 0,825 & 0,117 & 0,654 & 7,067 & 0,000 \\
\hline
\end{tabular}

a. Dependent Variable: Lender's Intention

A key challenge for personal investors in $\mathrm{P} 2 \mathrm{P}$ lending marketplaces is the effective allocation of their money across different loans by accurately assessing each loan's credit risk (Guo, Zhou, Luo, Liu, \& Xiong, 2016). Traditional rating-based assessment models cannot meet individual investor's needs in P2P lending since they do not provide an explicit mechanism for asset allocation. Hence, it is proposed to use the instance-based decision model for risk assessment in $\mathrm{P} 2 \mathrm{P}$ lending.

The research results are in line with research by Chen, Lou, and Van Slyke (2015). The perceived risk does not have an impact in determining the interest of lenders to provide loans in P2P lending. However, these risks can be mitigated through the benefits derived from these investments. It is known that loans through $\mathrm{P} 2 \mathrm{P}$ lending platforms tend to provide benefits, especially the higher interest rates for lenders compared to conventional financial institutions. The main advantage of $\mathrm{P} 2 \mathrm{P}$ lending is that borrowers can get a loan at a lower rate without collateral. Moreover, the lender can obtain a higher return on his investments (Pokorná \& Sponer, 2016).

Moreover, fintech, as an innovation platform in the financial sector, cannot act as a moderating variable to strengthen the effect of risk and benefit on the lender's intention. However, when fintech is tested as an independent variable, it directly impacts the lender's intention. The users' acceptance of mobile P2P lending applications is significantly influenced by perceived ease of use, perceived usefulness, and user satisfaction (Lee, 2017). These indicators, in turn, influence the attitude towards using mobile P2P lending application and intention to use.

One of the effects of using financial technology is a multi-sided platform (Iman, 2018). Through this platform, it can bring the business model together with various user groups. They raise interactions that can cause mutual connectivity between users and consumers. Another benefit of disruptive innovations is the process that products and services are offered in simple applications. It causes market penetration to occur at a level that can replace the existing incumbents. Through the presence of fintech, borrowers will easily find lenders who are willing to provide funds for their investments. Likewise, lenders can easily distribute funds in a fast and easy process that does not need complicated standard rules. 
Table 5 The Results of the Third Hypothesis

\begin{tabular}{|c|c|c|c|c|c|c|}
\hline Model & $\mathbf{R}$ & R-Squared & $\begin{array}{l}\text { Adjusted } \\
\text { R-Squared }\end{array}$ & $\begin{array}{l}\text { Std. Error } \\
\text { of the } \\
\text { Estimate }\end{array}$ & \multicolumn{2}{|c|}{ Durbin-Watson } \\
\hline 1 & $0,824^{\mathrm{a}}$ & 0,679 & 0,590 & 0,5864 & \multicolumn{2}{|c|}{2,041} \\
\hline \multicolumn{7}{|c|}{$\begin{array}{l}\text { a. Predictors: (Constant), Int_5, Collateral, Benefit, Capacity, Capital, Character, Fintech, Int_3, Int_1, } \\
\text { Int_4, and Int_2 }\end{array}$} \\
\hline \multicolumn{7}{|c|}{ ANOVA $^{\mathrm{a}}$} \\
\hline Model & & $\begin{array}{l}\text { Sum of } \\
\text { Squares }\end{array}$ & \multicolumn{2}{|r|}{$\begin{array}{l}\text { Mean } \\
\text { Square }\end{array}$} & $\mathbf{F}$ & Sig. \\
\hline \multirow[t]{3}{*}{1} & Regression & 29,055 & 11 & 2,641 & \multirow[t]{3}{*}{7,682} & \multirow[t]{3}{*}{0,000} \\
\hline & Residual & 13,754 & 40 & 0,344 & & \\
\hline & Total & 42,809 & 51 & & & \\
\hline \multicolumn{7}{|c|}{ a. Dependent Variable: Lender's Intention } \\
\hline \multicolumn{7}{|c|}{$\begin{array}{l}\text { b. Predictors: (Constant), Int_5, Collateral, Benefit, Capacity, Capital, Character, Fintech, Int_3, Int_1, } \\
\text { Int_4, and Int_2 }\end{array}$} \\
\hline \multicolumn{7}{|c|}{ Coefficients $^{a}$} \\
\hline \multirow[t]{2}{*}{ Model } & & \multicolumn{2}{|c|}{$\begin{array}{l}\text { Unstandardized } \\
\text { Coefficients }\end{array}$} & $\begin{array}{l}\text { Standardized } \\
\text { Coefficients }\end{array}$ & & \\
\hline & & B & Std. Error & Beta & $\mathbf{t}$ & Sig. \\
\hline \multirow[t]{12}{*}{1} & (Constant) & 4,086 & 6,240 & & 0,655 & 0,516 \\
\hline & Benefit & 1,336 & 0,866 & 0,903 & 1,544 & 0,130 \\
\hline & Capacity & $-1,372$ & 1,745 & $-0,642$ & $-0,786$ & 0,436 \\
\hline & Collateral & $-1,161$ & 0,990 & $-1,007$ & $-1,173$ & 0,248 \\
\hline & Capital & 1,575 & 1,181 & 0,977 & 1,333 & 0,190 \\
\hline & Character & $-0,943$ & 1,014 & $-0,586$ & $-0,930$ & 0,358 \\
\hline & Fintech & $-0,271$ & 1,520 & $-0,214$ & $-0,178$ & 0,859 \\
\hline & Int_1 & $-0,162$ & 0,209 & $-0,814$ & $-0,777$ & 0,442 \\
\hline & Int_2 & 0,335 & 0,422 & 1,513 & 0,794 & 0,432 \\
\hline & Int_3 & 0,231 & 0,214 & 1,182 & 1,078 & 0,287 \\
\hline & Int_4 & $-0,435$ & 0,307 & $-2,117$ & $-1,418$ & 0,164 \\
\hline & Int_5 & 0,220 & 0,246 & 1,019 & 0,893 & 0,377 \\
\hline
\end{tabular}

a. Dependent Variable: Lender's Intention

Moreover, the ease of fintech also needs to be anticipated by the government. According to Suryono, Purwandari, and Budi (2019), P2P lending problems should be identified. These are information asymmetry, determination of borrower's scores, moral hazard, investment decisions, regulations and policies, and feasibility of P2P lending platform.

\section{CONCLUSIONS}

The research analyzes the impact of $4 \mathrm{C}$ credit factors and the benefits that lenders will receive, and the benefits of fintech on lenders' interest in placing their funds on the P2P lending platform. The results show that none of the potential risk factors noted by lenders can influence the lenders' interest in giving loans. Benefit factors such as large interest, speed, and duration significantly affect lenders to provide loans. Meanwhile, the utilization of fintech in moderating the influence of risk and benefit does not have a significant effect. It turns out that fintech has a direct effect because of its practicality, simplicity, and speed. Those factors influence lenders in lending their money.

The practical implication of the research is to reduce the potential risk that lenders will face. It is necessary that lenders must pay attention to the $4 \mathrm{C}$ of the borrowers. Lenders must also look at P2P platforms which are legally managed in terms of operational permits, management, and track records of fintech managers. For P2P lending companies, it is necessary to provide complete information and credit analysis regarding borrowers' conditions to reduce the 
potential risk for lenders. Then, in increasing fintech applications in Indonesia, the government should make policies that protect the community, especially lenders and borrowers, to take advantage of the fair and legal platform.

The research has a limited number of respondents who have ever provided $\mathrm{P} 2 \mathrm{P}$ lending loans. Hence, further research must collaborate with one of the platforms to find more respondents. Then, it can analyze the sides of borrowers and platform providers in further analysis.

\section{ACKNOWLEDGEMENT}

The researcher would like to thank the Atma Jaya Catholic University of Indonesia for giving full support, including the fund, which is necessary to complete the research.

\section{REFERENCES}

Alt, R., Beck, R., \& Smits, M. T. (2018). Fintech and the transformation of the financial industry. Electronic Markets, 28, 235-243.

Bachmann, A., Becker, A., Buerckner, D., Hilker, M., Kock, F., Lehmann, M., ... \& Funk, B. (2011). Online peer-to-peer lending-a literature review. Journal of Internet Banking and Commerce, 16(2), 1-18.

Baiden, J. E. (2011). The 5 C's of credit in the lending industry. SSRN Electronic Journal.

Byanjankar, A. (2017). Predicting credit risk in Peer-toPeer lending with survival analysis. In 2017 IEEE Symposium Series on Computational Intelligence (SSCI). https://doi.org/10.1109/ssci.2017.8280927

Chen, D., Lou, H., \& Van Slyke, C. (2015). Toward an understanding of online lending intentions: Evidence from a survey in China. Communications of the Association for Information Systems, 36, 317-336. https://doi.org/10.17705/1 cais.03617

Cummins, M., Lynn, T., Mac an Bhaird, C., \& Rosati, P. (2019). Addressing information asymmetries in online Peer-to-Peer lending. In Disrupting finance (pp. 15-31). Palgrave Pivot, Cham.

Fintechnews Singapore. (2018). Fintech Indonesia report 2018 - The state of play for fintech Indonesia. Retrieved February $13^{\text {th }} 2019$ from https:// fintechnews.sg/20712/indonesia/fintech-indonesiareport-2018/

Gunadi, W. (2018). Regulasi fintech pada era Industri 4.0. In Konferensi Digital Transformation \& Industry 4.0.

Guo, Y., Zhou, W., Luo, C., Liu, C., \& Xiong, H. (2016). Instance-based credit risk assessment for investment decisions in P2P lending. European Journal of Operational Research, 249(2), 417-426. https://doi. org/10.1016/j.ejor.2015.05.050

Hutapea, R. (2020). Minimalisasi risiko kredit (NPL) pada fintach Peer to Peer lending melalui kewajiban pelaporan SLIK OJK. Jurnal Ilmiah Mandala Education, 6(2), 241-253.

Iman, N. (2018). Assessing the dynamics of fintech in Indonesia. Investment Management and Financial Innovations, 15(4), 296-303. https://doi. org/10.21511/imfi.15(4).2018.24

Jiang, J., Liao, L., Wang, Z., \& Zhang, X. (2021). Government affiliation and peer-to-peer lending platforms in China. Journal of Empirical Finance, 62(June), 87106. https://doi.org/10.1016/j.jempfin.2021.02.004

Lee, S. (2017). Evaluation of mobile application in user's perspective: Case of P2P lending apps in fintech industry. TIIS, 11(2), 1105-1117. https://doi. org/10.3837/tiis.2017.02.027

Leong, C., Tan, B., Xiao, X., Tan, F. T. C., \& Sun, Y. (2017). Nurturing a fintech ecosystem: The case of a youth microloan startup in China. International Journal of Information Management, 37(2), 92-97. https://doi. org/10.1016/j.ijinfomgt.2016.11.006

Lin, X., Cai, S., Xu, D., \& Fu, X. (2015). Judging online Peer-To-Peer lending behavior: An integration of dual system framework and two-factor theory. In PACIS (p. 138).

Moti, H. O., Masinde, J. S., Mugenda, N. G, \& Sindani, M. N. (2012). Effectiveness of credit management system on loan performance: Empirical evidence from micro finance sector in Kenya. International Journal of Business, Humanities and Technology, 2(6), 99-108.

Pokorná, M., \& Sponer, M. (2016). Social lending and its risks. Procedia-Social and Behavioral Sciences, 220, 330-337. https://doi.org/10.1016/j. sbspro.2016.05.506

Riyanto, B. (2013). Dasar-dasar pembelanjaan perusahaan. Yogyakarta: Andi.

Ross, S. A., Westerfield, R., \& Jordan, B. D. (2016). Fundamentals of corporate finance. New York: McGraw Hill Education.

Ryu, H. S. (2018). What makes users willing or hesitant to use fintech?: The moderating effect of user type. Industrial Management \& Data Systems, 118(3), 541-569. https://doi.org/10.1108/imds-07-20170325

Serrano-Cinca, C., Gutiérrez-Nieto, B., \& López-Palacios, L. (2015). Determinants of default in P2P lending. PLoS ONE 10(10), 1-22. https://doi.org/10.1371/ journal.pone.0139427

Stern, C., Makinen, M., \& Qian, Z. (2017). Fintechs in China - With a special focus on Peer to Peer lending. Journal of Chinese Economic and Foreign Trade Studies, 10(3), 215-228. https://doi.org/10.1108/ jcefts-06-2017-0015

Sukmaningsih, D. W. (2018). A model for lender-borrower trust in Peer-to-Peer lending. ComTech: Computer, Mathematics and Engineering Applications, 9(1), 15-24. https://doi.org/10.21512/comtech.v9i1.4287

Suryono, R. R., Purwandari, B., \& Budi, I. (2019). Peer to Peer (P2P) lending problems and potential solutions: A systematic literature review. Procedia Computer Science, 161, 204-214. https://doi.org/10.1016/j. procs.2019.11.116

Unsal, O., \& Rayfield, B. (2019). Trends in financial innovation: Evidence from fintech firms. In J. J. Choi \& B. Ozkan (Eds.), Disruptive innovation in 
business and finance in the digital world. Emerald Publishing Limited.

Zavolokina, L., Dolata, M., \& Schwabe, G. (2016). The fintech phenomenon: Antecedents of financial innovation perceived by the popular press. Financial Innovation, 2(1), 1-16. https://doi.org/10.1186/ s40854-016-0036-7 